\title{
MOBILE LEARNING SEBAGAI MODEL PEMBELAJARAN YANG EFEKTIF DAN INOVATIF
}

Oleh: Bambang Warsita *)

\section{Abstrak}

Mobile learning (m-learning) merupakan sebuah model pembelajaran yang mengadopsi perkembangan teknologi seluler dan perangkat handphone (HP) yang dimanfaatkan sebagai sebuah media pembelajaran. M-learning dikembangkan dengan format multimedia yang menyajikan teks, gambar, audio dan meminimalkan video dan animasi karena alasan keterbatasan content size agar mudah diakses melalui HP sehingga menjadi bahan belajar yang menarik dan mudah dipahami. M-learning merupakan model pembelajaran alternatif yang memiliki karakteristik tidak tergantung tempat dan waktu. Potensi dan prospek pengembangan mobile learning ke depan, sangat terbuka lebar mengingat kecenderungan masyarakat yang semakin dinamis dan mobile serta tuntutan kebutuhan pendidikan yang berkualitas dan beragam. Konsep pembelajaran tersebut di harapkan dapat mendorong terwujudnya suasana pembelajaran yang efektif dan inovatif sehingga dapat memotivasi semangat belajar peserta didik dan guru.

Kata kunci: mobile learning, m-learning, e-learning, pembelajaran efektif, pembelajaran inovatif.

\section{A. LATARBELAKANG DAN PERMASALAHAN}

Penggunaan Teknologi Informasi dan Komunikasi (TIK) di dalam dunia pendidikan terus berkembang dalam berbagai strategi dan pola, yang pada dasarnya dapat dikelompokkan ke dalam sistem e-learning (electronic learning) sebagai model pembelajaran yang memanfaatkan perangkat elektronik dan media digital, maupun mobile learning sebagai bentuk pembelajaran yang memanfaatkan perangkat dan teknologi komunikasi bergerak. TIK banyak menciptakan terobosan baru dalam pembelajaran. Salah satu contoh adalah pembelajaran berbasis mobile (device by handphone) telepon seluler yaitu mobile learning.
Perkembangan teknologi bergerak (mobile technology) sangat cepat, baik dalam hal jaringan maupun peralatan (devices), telah menyebabkan teknologi ini melaju dengan akselerasi yang menakjubkan. Tak heran bila pengguna HP saat ini sangat mudah ditemui, bahkan di pelosok daerah pedesaan dan pedalaman. Perkembangan teknologi mobile yang cepat terjadi pada konektifitas seperti $\mathrm{Wi}-\mathrm{Fi}$, third generation (3g) mobile communications, serta Worlwide Interoperability for Microwave Access (WiMAX), dan pada peralatan (devices) seperti smart phones, pocket PCs, tablet PCs, serta berbagai variasi pesawat $P$ ersonal Data Assistants (PDAs).

*) Drs. Bambang Warsita, M. Pd., adalah staf Pusat Teknologi Informasi dan Komunikasi Pendidikan (Pustekkom) Departemen Pendidikan Nasional. 
Faktor pendorong dalam pengembangan dan penerapan mobile learning sebagai sebuah model baru dalam kegiatan pembelajaran, diantaranya adalah tingkat penetrasi perangkat bergerak yang sangat tinggi, tingkat penggunaan yang relatif mudah, mudah diterima, dan harga perangkat yang semakin terjangkau dibandingkan perangkat komputer personal (personal computer/PC), tarif yang semakin murah dan fitur yang semakin berkembang dan canggih, jangkauan layanan wireless/seluler semakin luas. Selain itu mobile learning dapat membentuk paradigma pembelajaran fleksibel yang dapat dilakukan dimanapun dan kapanpun.

Beberapa potensi dan peluang menggunakan perangkat seluler sebagai media pembelajaran (e-learning), yaitu: 1) pengguna telepon seluler di Indonesia yang mencapai lebih dari 96.410 .000 , teledensitas 36,39\% dengan tingkat prosentase pertumbuhan pelanggan mencapai $28,26 \%$ pertahun. (Balitbang Depkominfo, 2006), Sebagian dari jumlah pengguna ini adalah peserta didik, pendidik dan kalangan akademisi. Bahkan sebuah survei menunjukkan bahwa tingkat kepemilikan HP para peserta didik ternyata sangat tinggi. Telepon genggam yang dimiliki peserta didik ini rata-rata memiliki fitur-fitur yang sudah canggih dan memiliki kapabilitas untuk menjalankan konten-konten berupa multimedia maupun aplikasi software. 2) adanya kemudahan akses internet melalui perangkat telepon seluler seperti blackberry, iPhone, PDA, maupun smartphonesmartphone lain, 3) akses dan transfer data menggunakan jaringan telepon seluler semakin murah dan cepat, 4) pembuatan aplikasi-aplikasi untuk smartphone yang semakin mudah, dengan menggunakan J2ME maupun BREW. Fenomena-fenomena tersebut menjadi bahan pertimbangan dalam pengembangan mobile learning.

Realitasnya saat ini masih sangat sedikit upaya pengembangan konten-konten pembelajaran berbasis perangkat bergerak yang dapat diakses secara luas. Kebanyakan konten yang beredar di lapangan masih didominasi konten hiburan dengan kandungan pendidikan yang minim serta hasil produksi dari luar negeri yang memiliki latar budaya yang berbeda dengan negera kita.
Kenyataan ini memunculkan kebutuhan akan perlunya pengembangan konten/aplikasi berbasis perangkat bergerak yang lebih banyak, beragam, murah, dan membelajarkan, serta mudah diakses. Selain itu, pengembangan konten/aplikasi mobile learning harus dapat memacu (merangsang) dan memicu (menumbuhkan) peserta didik untuk belajar. Pertanyaannya bagaimana mengembangkan mobile learning sebagai model pembelajaran yang efektif dan inovatif? Bagaimana mengembangkan model pembelajaran dengan memanfaatkan teknologi seluler ini?

\section{B. KAJIAN LITERATUR}

\section{Pengertian Mobile Learning}

Menurut Clark Quinn mobile learning didefinisikan sebagai... The intersection of mobile computing and e-learning: accessible resources wherever you are, strong search capabilities, rich interaction, powerful support for effective learning, and performance-based assessment. ELearning independent of location in time or space (Wijaya, 2006). Mobile learning merupakan model pembelajaran yang memanfaatkan TIK. Mobile learning menyediakan materi pembelajaran yang dapat di akses oleh peserta didik pada setiap saat dan diberikan sajian visualisasi materi yang menarik.

Mobile learning adalah suatu model pembelajaran yang melibatkan perangkat (device) bergerak sehingga peserta didik dapat mengakses materi pembelajaran, petunjuk belajar dan aplikasi pembelajaran tanpa dibatasi oleh ruang dan waktu, dimanapun dan kapanpun mereka berada.

Mobile learning didefinisikan sebagai elearning melalui perangkat komputasi mobile (Yonatan Andy, 2007). M-learning adalah menyampaikan materi pembelajaran elektronik melalui komputasi mobile sehingga dapat diakses peserta didik dari mana saja dan kapan saja. Pada umumnya, perangkat mobile berupa telepon seluler digital dan PDA (Ally, 2004). Namun, secara umum sebagai perangkat apapun yang 
berukuran cukup kecil, dapat bekerja sendiri, dapat dibawa setiap waktu dalam kehidupan sehari-hari, dan dapat digunakan untuk beberapa bentuk pembelajaran. Perangkat kecil ini dapat sebagai alat mengakses konten, baik disimpan secara lokal pada device maupun dapat dijangkau melalui interkoneksi. Perangkat ini juga dapat menjadi alat untuk berinteraksi dengan orang lain, baik melaui suara, maupun saling bertukar pesan tertulis, gambar diam dan gambar bergerak.

Adapun karakteristik mobile learning, yaitu: 1) merupakan bagian dari elearning, memanfaatkan TIK elektronik dan digital; 2) dapat diakses dimanapun dan kapanpun; 3) menyediakan fasilitas knowledge sharing dan visualisasi pengetahuan yang atraktif dan interaktif; dan 4) tidak semua materi pembelajaran cocok memanfaatkan m-Learning mengingat memiliki ukuran file yang terbatas (Clark Quinn, 2000).

\section{Pengembangan Mobile Learning}

Dengan degala potensinya teknologi bergerak, khususnya HP sangat mungkin dioptimalkan penggunaannya untuk pembelajaran karena menawarkan banyak peluang, seperti sebagai berikut:

a. Portabilitas, dengan ukuran fisik yang sangat portable, perangkat yang ada saat ini telah memiliki kemampuan yang sangat baik dalam hal multimedia akses internet, akses perangkat lunak komersial, maupun kemampuan lainnya yang sangat kondusif dengan kegiatan pembelajaran.

b. Menghemat tempat, ukurannya kecil dan ringan beratnya, telepon dan komputer genggam tidak membutuhkan tempat khusus dan mudah dipindahkan dari satu ruangan ke ruangan yang lain, apalagi karena tidak membutuhkan konektifitas kabel.

c. Konektifitas, dengan kemampuan dan kemudahan akses instant ke sumbersumber internet, email, dan forum virtual, peralatan bergerak ini akan semakin mampu memfasilitasi kegiatan pembelajaran peserta didik, mahasiswa, guru, dosen, instruktur, fasilitator, dan sebagainya.

d. Kelengkapan fungsi, peralatan genggam modern kini memiliki fitur dan kemampuan fungsi yang semakin mendekati fungsi komputer desktop, akses internet dan kemampuan multimedia. Kedua kemampuan inilah yang paling berpotensi mendukung proses pembelajaran yang interaktif dan inovatif.

e. Instan, umumnya HP beroperasi secara instan, jadi tidak membutuhkan waktu booting seperti halnya komputer laptop ataupun desktop.

f. Long battery life, dengan kelebihan ini, HP dapat dimanfaatkan tanpa harus terganggu dengan koneksi kabel daya, sehingga bisa dimanfaatkan baik dalam ruangan maupun luar ruangan atau dimanapun peserta didik belajar.

g. Kemampuan recording dan processing information.

h. Kemampuan memanipulasi, menginterpretasi, serta membagi teks sehingga files dan informasi dapat ditransfer dari peserta didik ke guru ataupun sebaliknya secara cepat. Kemampuan ini juga memudahkan pembentukan tim dan kolaborasi dalam proses pembelajaran.

i. Inklusif, dengan HP peserta didik yang mengalami kendala psikis dan fisik, dapat mengikuti pembelajaran, secara langsung maupun tidak langsung.

j. Group/teamwork, HP memungkinkan peserta didik berinteraksi antara satu dengan lainnya secara lebih efektif.

Potensi dan peluang tersebut telah membuka kemungkinan untuk mengembangkan model-model pembelajaran baru yang inovatif secara lebih efektif dan produktif. Meskipun begitu, implementasi mobile learning perlu memperhatikan keterbatasan dari peralatan bergerak (mobile devices) yaitu: 1) harga, 2) fungsi yang masih terbatas, 3) biaya konektifitas, 4) keterbatasan keyboard, 5) ukuran layar yang kecil, dan lain-lain. 
Aplikasi-aplikasi mobile learning perlu memperhatikan beberapa aspek. Salah satunya adalah bagaimana aplikasi tersebut dikemas seringan mungkin sehingga memudahkan peserta didik menggunakan untuk belajar melalui layar monitor yang kecil. Tentunya dengan tetap memperhatikan aspek estetika serta berbagai teori multimedia pembelajaran. Selain itu, perlu memperhatikan dalam mengakses secara online, aplikasi mobile learning tersebut tidak memberatkan peserta didik dalam membayar biaya untuk mengakses internet melalui seluler yang dihitung per satuan data yang diunduh. Kemudian ada juga batasan mengenai jenis-jenis ekstensi yang dapat ditampilkan dan mana yang tidak pada perangkat seluler (Ardiansyah, 2009).

Aplikasi-aplikasi yang dapat digunakan untuk mobile learning, diantaranya adalah MOMO (Mobile Moodle), MLE (Mobile Learning Environment), Learning Mobile Author, Desire2Learn 2GO, dan ReadyGo, Morning dan aplikasi pembelajaran Matematika melalui ponsel yakni Mathematic Mobile Learning (MML). Aplikasi perangkat lunak ini mampu menggabungkan konten-konten pembelajaran seperti teks, audio dan video sehingga menjadi lebih interaktif.

Jenis aplikasi yang saat ini banyak digunakan mobile learning, yaitu: aplikasi berbasis WAP/WML, aplikasi Java, aplikasi Symbian, dan lain-lain. Kedepan akan muncul banyak aplikasi-aplikasi lain yang gratis atau membeli, yang fokus pada satu bidang atau yang umum, semuanya memiliki ciri khas masingmasing. Tinggal memilih mana yang akan digunakan sesuai dengan kebutuhan, kemampuan divais, karakteristik peserta didik, karakteristik konten, dan piranti yang digunakan baik hardware maupun softwarenya.

Kebanyakan divais saat ini telah mendukung penyajian konten berformat teks. Hampir semua HP yang beredar saat ini telah mendukung penggunaan SMS. Kebutuhan memori yang relatif kecil memuat konten berbasis teks lebih mudah diimplementasikan. Namun, keterbatasan jumlah karakter yang dapat ditampilkan harus menjadi pertimbangan dalam mengembangkan konten pembelajaran sehingga perlu strategi khusus agar konten pembelajaran dapat disampaikan secara tepat dan efektif. Contoh aplikasi pembelajaran berbasis teks (SMS) adalah Study TXT.

Perangkat bergerak yang ada sekarang telah mampu menyajikan gambar. Kualitas gambar yang ditampilkan dapat beragam dari tipe monokrom sampai gambar berwarna berkualitas tinggi tergantung kemampuan divais. File gambar yang didukung oleh divais umumnya bertipe PNG, GIF, JPG. Pemberian gambar dalam konten pembelajaran untuk melengkapi dan memperjelas uraian teks.

Banyak perangkat bergerak saat ini telah mampu menyajikan konten berformat audio. Beberapa tipe file yang digunakan di lingkungan divais bergerak antara lain rm, mp3, amr dan lain-lain. File audio biasanya memiliki ukuran yang cukup besar, maka perlu diolah lebih dahulu agar dapat digunakan di lingkungan divais bergerak yang kapasitas memorinya relatif kecil.

Beberapa tipe divais bergerak telah mampu menyajikan file video dan animasi walaupun dalam kualitas dan ukuran yang terbatas. Format file yang didukung oleh divais bergerak antara lain adalah 3gp, MPEG, MP4, dan lain-lain. Sama seperti file audio, kebanyakan file video memiliki ukuran yang cukup besar sehingga harus dikonversi dan disesuaikan dengan keterbatasan divais.

Sebagai contoh format program mobile learning yang dikembangkan oleh Balai Pengembangan Multimedia Semarang, yaitu mobiledukasi (m-edukasi). Medukasi dikembangkan menggunakan hardware adobe supported dengan konfigurasi PHP dan MySQL. Softwarenya menggunakan flash lite. Jenis media yang diproduksi adalah multimedia dengan menyajikan teks, gambar, audio dan meminimalkan video dan animasi karena alasan keterbatasan 
content size agar mudah diakses melalui HP. Ke depan, program m-edukasi akan dikembangkan dengan menambah atau mengkombinasikan dengan format lain seperti Java, dan sejenisnya.

Pengembangan konten mobile learning dapat dijelaskan sebagai berikut:

a. Tipe versi produk (by type of version), dalam progam m-edukasi dikembangkan 2 (dua) versi berdasarkan pada ukuran layar (screen size), yaitu: (1) program dengan screen size 128 x 160 pixel, dan (2) program dengan screen size $240 \times 320$ pixel.

b. Tipe aplikasi (by type of application), mobile learning dikembangkan dengan menggunakan model format sajian berikut:

1) Drill and practice

Format sajian ini dimaksudkan untuk melatih peserta didik agar memiliki keterampilan atau memperkuat penguasaan suatu konsep. Program menyediakan serangkaian soal atau pertanyaan yang biasanya ditampilkan secara acak, sehingga setiap kali menggunakan soal atau pertanyaan yang tampil selalu berbeda, atau paling tidak dalam kombinasi yang berbeda. Program ini dilengkapi dengan jawaban yang benar, lengkap dengan penjelasannya sehingga peserta didik bisa memahami suatu konsep tertentu. Pada bagian akhir, peserta didik bisa melihat skor akhir yang dicapai, sebagai indikator untuk mengukur tingkat keberhasilan dalam memecahkan soal-soal yang diajukan.

2) Tutorial

Format sajian m-learning ini menyajikan materi secara tutorial, layaknya tutorial oleh guru atau instruktur. Materi pembelajaran tentang suatu konsep disajikan dengan teks, gambar baik diam atau bergerak, dan grafik. Kemudian setelah diperkirakan peserta didik membaca, menginterpretasikan dan menyerap konsep itu, diajukan serangkaian pertanyaan atau tugas. Jika jawaban atau respon peserta didik benar, kemudian dilanjutkan dengan materi berikutnya. Jika jawaban atau respon peserta didik salah, maka peserta didik harus mengulang memahami konsep tersebut secara keseluruhan ataupun pada bagian-bagian tertentu saja (remedial). Pada bagian akhir diberikan tes untuk mengukur tingkat pemahaman peserta didik atas konsep atau materi yang disampaikan.

\section{3) Simulasi}

Mobile learning dengan format sajian ini mencoba menyamai proses dinamis yang terjadi di dunia nyata, misalnya untuk mensimulasikan pesawat terbang, dimana peserta didik seolah-olah melakukan aktivitas menerbangkan pesawat terbang, menjalankan usaha kecil, atau pengendalian pembangkit listrik tenaga nuklir, dan lain-lain. Format sajian ini mencoba memberikan pengalaman masalah dunia nyata yang memiliki resiko besar, seperti pesawat akan jatuh atau menabrak, perusahaan akan bangkrut, atau terjadi malapetaka nuklir.

4) Games edukasi

Bentuk permainan yang disajikan supaya tetap mengacu pada proses pembelajaran, mobile learning berformat ini diharapkan peserta didik dapat belajar sambil bermain. Dengan demikian, peserta didik tidak merasa bahwa mereka sesungguhnya sedang belajar.

5) Percobaan/eksperimen Format ini mirip dengan format simulasi, namun lebih ditujukan pada kegiatan-kegiatan yang 
bersifat eksperimen, seperti kegiatan praktikum di laboratorium IPA, biologi atau kimia. Program menyediakan serangkaian peralatan dan bahan, kemudian peserta didik diminta melakukan percobaan atau eksperimen sesuai petunjuk dan kemudian mengembangkan eksperimen-eksperimen lain berdasarkan petunjuk tersebut. Pada akhir kegiatan pembelajaran diharapkan peserta didik dapat menjelaskan suatu konsep atau fenomena tertentu berdasarkan eksperimen yang mereka lakukan secara maya tersebut.

6) Ensiklopedi

Kumpulan istilah dengan penjelasan lengkap bukan hanya dengan deskripsi verbal, melainkan juga dengan gambar atau media lain.

Pengembangan konten mobile learning dapat dilakukan berdasarkan platform, desain antar muka pengguna (user interface design), proses pengembangan (development process), komponenkomponen pengembangan sistem (technical resources/system requirements) dan format distribusi (distribution format) sebagai berikut:

a. Platform (by platform)

Ada beberapa platform yang bisa digunakan untuk pengembangan program mobile learning, antara lain: Flash Lite, Java, Symbian, Windows Mobile, Aplikasi WAP. Sebagai contoh Balai Pengembangan Multimedia (BPM) Semarang, telah dan sedang mengembangkan mobile learning dengan menggunakan platform flash lite.

\section{Flash Lite}

Platform ini dikembangan mengunakan adobe flash. Flash lite player adalah versi ringan dari flash player. Flash lite sendiri berbasiskan teknologi flash 4 scripting engine yang khusus ditujukan pada aplikasi mobile. Untuk membangun aplikasi mobile dalam lingkungan flash lite tidak dibutuhkan banyak kode program, tetapi pengembang dapat menggunakan Integrated Development Environment berbasis grafis, yaitu dengan aplikasi Macromedia Flash Professional 8. Bahasa scripting yang digunakan dalam Flash Lite adalah Action Script, sama seperti Flash, tetapi memiliki keterbatasan fitur.

Platform ini dapat di jalankan pada HP yang support flash lite. Platform ini biasanya digunakan HP untuk aplikasi wallpaper atau screensaver yang berwujud animasi. Pada saat ini sudah banyak HP yang support flash lite. Dalam pengunaannya, file flash dapat dijalankan langsung tanpa proses instalasi. Dalam proses pembelajarannya user membuka mobile learning ini mengunakan flash lite player. Jadi file flash ini merupakan data yang dapat dijalankan oleh flash lite player. File data dari mobile learning ini bisa di distribusikan mengunakan web, wap, bluetoot, infrared, flashdisk, CD dan media penyimpanan yang lain. Dengan kata lain dalam platform ini user dapat belajar secara offline.

b. Desain antar muka pengguna (user interface design)

Mobile learning sengaja dirancang dengan memperhatikan desain antarmuka bagi pengguna (user interface design), seperti berikut ini:

1) Opening, misalnya mobile learning yang dikembangkan oleh BPM Semarang, Pada bagian opening akan dimunculkan beberapa tampilan, yaitu: Logo Tut Wuri Handayani, Logo mobile learning Tulisan BPM Pustekkom Kemdiknas, warna biru (kode: \#00FFFF) (muncul dengan efek transisi zoom from point secara bersamaan), Navigasi => "Masuk" dan "Keluar"., background opening berwarna hitam (kode : \#000000). 
2) Pendahuluan yang berisi judul program mobile learning dan apersepsi (bisa berupa animasi, perpaduan grafis dan teks, atau teks saja), pada tampilan pendahuluan tidak menggunakan fasilitas scroll, navigasi => "Menu" dan "Keluar", warna background disesuaikan dengan mata pelajaran.

3) Kompetensi, berisi uraian kompetensi yang akan dicapai oleh peserta didik setelah memanfaatkan program mobile learning, memuat navigasi => "Menu" dan "Keluar", warna background disesuaikan dengan mata pelajaran.

4) Materi pembelajaran

a. Berisi uraian materi pembelajaran yang akan dipelajari oleh peserta didik. Materi ini terbagi dalam beberapa menu, dimana peserta didik bisa memilih dengan bebas. Materi pembelajaran disajikan dalam beberapa jenis media, antara lain: teks, grafis, foto dan animasi.

b. Teks materi berwarna hitam (kode: \#000000).

c. Teks judul sub menu ditulis tebal (Bold).

d. Teks materi ditampilkan rata kiri (Left).

e. Teks materi disajikan dengan teknik halaman per halaman, menggunakan navigasi Lanjut ( $>$ ) dan Kembali (<), diberi keterangan posisi halaman.

f. Teks materi juga disajikan dengan teknik scroll ke Atas (^) dan ke Bawah (v).

g. Aturan pembuatan scroll maksimal 3 kali tinggi layar, \pm 500 pixel untuk program dengan ukuran layar 128x160 pixel, dan \pm 1000 pixel untuk program dengan ukuran layar 240x320 pixel. Jika lebih, disarankan untuk ditampilkan pada halaman selanjutya.

h. Teks yang menerangkan suatu istilah/nama asing ditulis miring (Italic).

5) Simulasi

a. Berisi simulasi yang menekankan penjelasan dari materi pembelajaran. Pada dasarnya simulasi mencoba memberikan pengalaman langsung bagi peserta didik untuk mengalami kondisi nyata.

b. Simulasi tidak selalu ada dalam program mobile learning, disesuaikan dengan kebutuhan di dalam topik yang dipilih.

6) Latihan Soal

a. Latihan soal ini dimaksudkan untuk melatih peserta didik sehingga memiliki kemahiran dalam suatu keterampilan atau memperkuat penguasaan suatu konsep. Program menyediakan serangkaian soal atau pertanyaan yang biasanya ditampilkan secara acak, sehingga setiap kali digunakan maka soal atau pertanyaan yang tampil selalu berbeda, atau paling tidak dalam kombinasi yang berbeda.

b. Program ini dilengkapi dengan jawaban yang benar, lengkap dengan penjelasannya sehingga diharapkan peserta didik akan bisa pula memahami suatu konsep tertentu. Pada bagian akhir, peserta didik bisa melihat skor akhir yang dicapai, sebagai indikator untuk mengukur tingkat keberhasilan dalam memecahkan soal-soal yang diajukan.

c. Latihan soal ditampilkan dalam program mobile learning dengan tipe drill and practice. 
7) Tes

a. Tes berisi soal-soal yang diperuntukkan bagi peserta didik untuk mengetahui sejauh mana penguasaan kompetensi yang telah dipelajari.

b. Pada bagian akhir, peserta didik bisa melihat skor akhir yang capai, sebagai indikator untuk mengukur tingkat keberhasilan dalam penguasaan kompetensi yang telah dipelajari.

c. Tes ditampilkan dalam program mobile learning dengan tipe tutorial.

8) Bantuan

a. Berupa panduan lengkap dalam penggunaan program.

b. Adapula keterangan berupa referensi materi terkait yang ada di website (http://www.medukasi.net)/wapsite Medukasi (BPM, 2009).

\section{Pemanfaatan Mobile Learning}

Mobile learning dapat diterapkan sebagai salah satu model pembelajaran pada satuan pendidikan formal seperti pada sekolah maupun perguruan tinggi. Bayangkan jika seorang peserta didik yang biasanya rajin tiba-tiba, suatu hari, tidak dapat mengikuti pelajaran karena sakit atau alasan penting lain. Namun, dia tidak terlalu risau. Peserta didik ini cukup mengambil HP, mengikuti pembelajaran kelasnya melalui video streaming atau video-calling, mengunduh aplikasi pembelajaran yang telah disediakan dalam bentuk aplikasi Java, mengunduh rekaman kegiatan pembelajaran dalam bentuk MP3 atau 3GP, mengikuti ulangan melalui WAP, dan aktifitas-aktifitas belajar lainnya. Mungkin terkesan futuristik, tetapi hal ini sebenarnya telah dapat dilakukan karena teknologi HP yang ada sekarang ini sudah cukup memungkinkan.

Mengingat proses pembelajaran pada setiap satuan pendidikan sekarang ini supaya diselenggarakan secara interaktif, inspiratif, menyenangkan, menantang, memotivasi peserta didik untuk berpartisipasi aktif, serta memberikan ruang yang cukup bagi prakarsa, kreativitas, dan kemandirian sesuai dengan bakat, minat, dan perkembangan fisik serta psikologis peserta didik (Pasal 19, PP No.19 th 2005 tentang Standar Nasional Pendidikan). Artinya kegiatan pembelajaran yang dilaksanakan sekarang ini harus memenuhi standar proses pembelajaran yaitu interaktif, inspiratif, menyenangkan, menantang, dan memotivasi (I2M3) peserta didik untuk belajar. Kegiatan pembelajaran tersebut akan dapat diwujudkan dengan salah satunya memanfaatkan m-learning.

Sebagai contoh model mobile learning yang dikembangkan oleh Balai Pengembangan Multimedia (BPM) Semarang UPT Pustekkom Kemdiknas yaitu mobiledukasi (m-edukasi) adalah salah satu model pembelajaran dengan menggunakan HP sebagai sarana untuk belajar. Sedangkan m-edukasi.net (http:/ /www.m-edukasi.net) merupakan portal penyedia layanan program m-edukasi yang dapat diakses melalui komputer personal $(\mathrm{PC})$ maupun HP.

Cara mendapatkan materi pembelajaran di m-edukasi yaitu: 1) buka situs www.medukasi.net atau wap.m-edukasi.net melalui PC atau HP, 2) pilih dan klik program yang diinginkan, 3) pilih dan klik judul program m-edukasi yang diinginkan, 4) klik download (materi akan ditransfer ke PC jika Anda mengakes melalui PC, materi akan tertransfer ke HP jika Anda mengakses melalui HP), 5) setelah materi tersimpan di PC Anda, lalu materi dapat di transfer ke HP dengan menggunakan kabel data, atau dengan menggunakan bluetooth. Bagi peserta didik yang mendownload melalui HP, program m-edukasi dapat langsung dimanfaatkan untuk kegiatan pembelajaran. Gambar tampilan web m-edukasi.net sebagai berikut: 


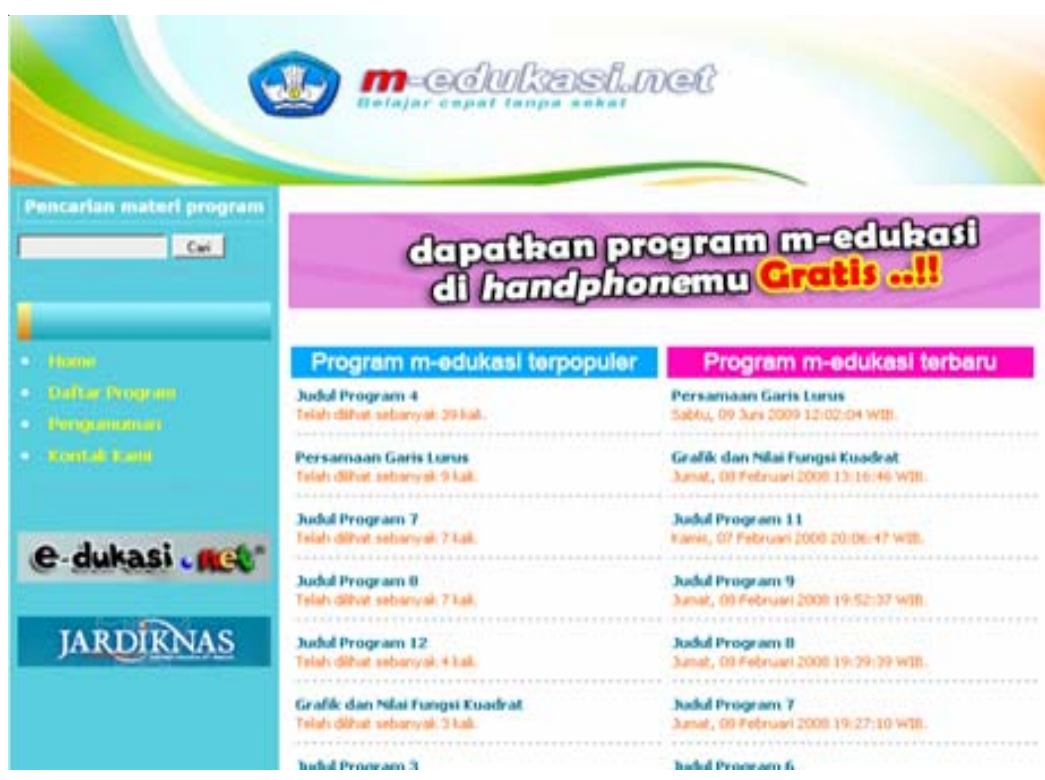

Gambar 1. Tampilan Web M-edukasi.net

Spesifikasi HP yang diperlukan agar dapat menjalankan program m-edukasi adalah semua merk dan jenis HP yang sudah dilengkapi dengan flash player dapat menjalankan program m-edukasi. Sebagian besar HP "middle end" yang diproduksi tahun 2007 ke atas sudah memiliki fitur flash lite player (untuk lebih jelasnya kunjungi website resmi adobe flash). Untuk HP yang tidak memiliki fitur flash lite player, download dan instal flash lite player sesuai dengan os atau platform HP pada link dibawah ini: Symbian S60 2 rd.

Device (perangkat akses) agar peserta didik dapat mengakses program Medukasi harus menggunakan HP dengan spesifikasi berikut: 1) size layar adalah $128 \times 160,2)$ resolusi yang digunakan 320 atau 340 , c) content size-nya maksimal $300 \mathrm{~kb}, 4$ ) di-support oleh flash lite, 5) memiliki fasilitas polyphonic, 6) memiliki perangkat transfer data, yaitu: bluethot, infra red atau kabel data.

Beberapa manfaat dari m-learning, yaitu: a) memberikan pembelajaran yang benar-benar dimanapun, kapanpun, dan terpersonalisasi; b) dapat digunakan untuk menghidupkan, atau menambah variasi pada pembelajaran konvensional; c) dapat digunakan untuk menghilangkan beberapa formalitas yang tidak menarik atau menakutkan, dan dapat membuat materi pembelajaran menjadi lebih menarik dan menyenangkan; d) dapat membantu memberikan dan mendukung pembelajaran literasi, numerasi dan bahasa; e) memfasilitasi pengalaman belajar baik secara individu maupun kolaboratif; f) dapat membantu melawan penolakan terhadap penggunaan TIK dengan menyediakan jembatan antara buta teknologi telepon seluler dan PC; g) telah dapat membantu peserta didik untuk tetap lebih fokus untuk waktu yang lebih lama; dan h) dapat membantu meningkatkan percaya diri dan penilaian diri dalam pendidikan (Gumbira, 2008).

\section{Mobile Learning Sarana untuk Meningkatkan Efektivitas Pembelajaran}

Belajar tidak mengenal usia dan tidak mengenal batas. Belajar kini bisa dimana saja dan kapan saja tanpa harus dibatasi oleh ruang dan waktu. Materi pembelajaran dapat diakses secara online. Maksudnya belajar bisa dimana saja dan kapan saja sepanjang masih ada jaringan operator seluler. Artinya peserta didik dapat belajar melalui telepon seluler (ponsel). Tidak ada notebook atau PDA, Ponsel pun bisa menjadi sarana penting dalam proses pembelajaran.

Mobile Learning merupakan model pembelajaran yang dilakukan antar tempat atau lingkungan dengan 
menggunakan teknologi yang mudah dibawa pada saat peserta didik berada pada kondisi mobile. Dengan berbagai potensi dan kelebihan yang dimilikinya, mobile Learning diharapkan akan dapat menjadi sumber belajar alternatif yang dapat meningkatkan efisiensi dan efektifitas proses dan hasil belajar peserta didik di Indonesia di masa mendatang.

M-learning bisa membantu peserta didik untuk belajar dimana saja dan kapan saja sesuai kebutuhan. M-learning merupakan bagian dari e-learning, pembelajaran menggunakan teknologi internet yang banyak digunakan diberbagai sekolah. Model pembelajaran ini merupakan suatu bentuk inovasi dalam membantu proses pembelajaran. Hal ini merupakan sebuah peluang bagaimana HP dimanfaatkan untuk pembelajaran, selain kegiatan pembelajaran dikelas. Pembelajaran dengan m-learning memang tidak akan sepenuhnya menggantikan pembelajaran, namun dengan menggunakan model ini akan lebih disesuaikan dilingkungan dimana computer aided learning tidak tersedia. Oleh karena itu, agar kegiatan pembelajaran lebih efektif perlu menggabungkan m-learning dengan pembelajaran lain, sehingga $m$-learning sebagai suplemen.

Contoh pada Yayasan TEI Bandung, mengembangkan model m-learning tingkat SMP untuk membantu kegiatan pembelajaran dengan memanfaatkan fasilitas perangkat mobile. Model $m$ learning ini akan mencakup: 1) materi pembelajaran, 2) forum komunikasi dalam pembelajaran antar user (dalam hal ini peserta didik dan guru), dan 3) latihan (ujian). Model m-learning ini dijalankan baik secara offline (materi pembelajaran disimpan terlebih dahulu didalam perangkat bergerak untuk dipelajari guru dan peserta didik kapan dan dimanapun) dan online (proses pembelajaran secara langsung terhubung kepada sistem untuk melakukan pengaksesan materi pembelajaran, soal dan berinteraksi dengan peserta didik dan guru, yang dilakukan kapan dan dimana saja asalkan memiliki akses internet).

Sebagai contoh lain, Universitas Terbuka (UT) selama ini pembelajaran online hanya dapat dilakukan melalui komputer yang terkoneksi dengan internet. Namun, dengan M-Learn UT kendala keterbatasan koneksi internet di daerah dapat diatasi dengan kemajuan teknologi komunikasi seluler yang sudah mempunyai fasilitas GPRS dan Web Base Course (WAP). Untuk kota-kota besar sudah berbasiskan HSDPA. Akhirnya UT memanfaatkan teknologi seluler untuk kegiatan pembelajaran secara online dengan menggunakan media HP yang telah dilengkapi dengan fasilitas GPRS dan Web Base Course (WAP). Tampilan m-learn UT dapat disajikan sebagai berikut:

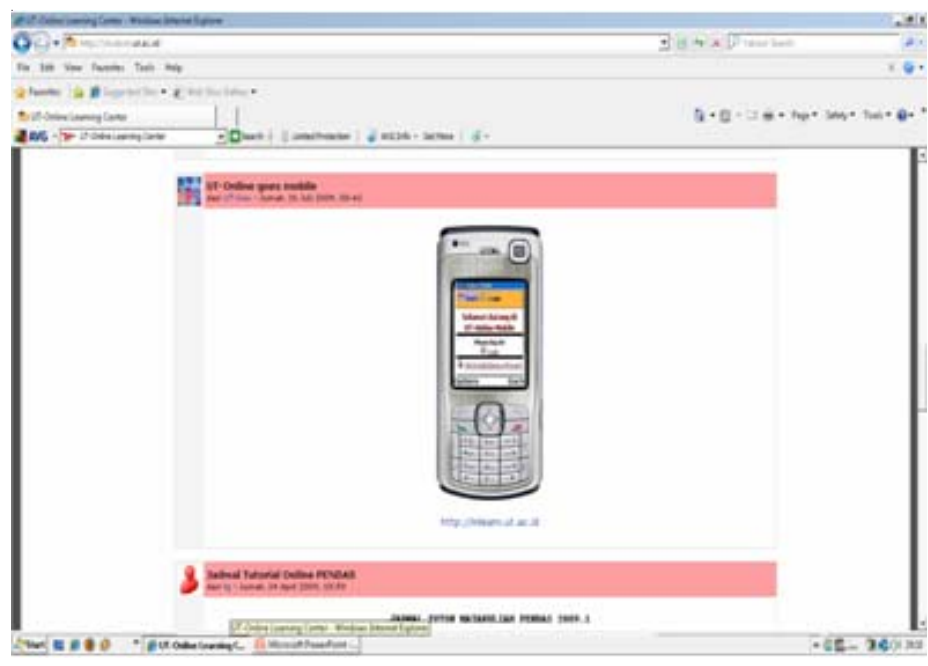

Gambar 2. m-learn UT 
M-Learn merupakan fasilitas tambahan untuk proses pembelajaran online melalui media HP ( $m$-learn=ut-online versi mobile), prinsip pembelajarannya sama seperti pada kegiatan tutorial online. $M$ learn dapat diakses melalui browser di HP dengan alamat http://mlearn.ut.ac.id.

Sebagai contoh lain, Pusat Pengembangan dan Pemberdayaan Pendidik dan Tenaga Kependidikan (PPPPTK) Matematika, Kementerian Pendidikan Nasional telah dan sedang mengembangkan mobile learning, khususnya untuk konten pembelajaran Matematika dan konten pendidikan secara umum dalam upaya menyediakan sumber belajar alternatif yang enovatif. Pengembangan mobile learning ini mengunakan aplikasi software Java dan
WAP serta memanfaatkan teknologi GPRS/CDMA dan/atau teknologi transfer lain seperti bluetooth, infrared, untuk transfer dan instalasi aplikasi. Perangkat yang dapat digunakan untuk pembelajaran ini adalah HP yang mendukung WAP dan Java.

Misalnya pembelajaran Matematika tentang topik Trigonometri adalah sebuah cabang matematika yang berhadapan dengan sudut segi tiga dan fungsi trigonometrik seperti sinus, cosinus, dan tangen. Aplikasi ini membahas beberapa hal dasar mengenai Trigonometri dari pengertian sinus, cosinus, tangen sampai dengan rumus identitas. Konten pembelajaran Matematika mobile learning yang dikembangkan PPPPTK Matematika ini tampilannya dapat disajikan dalam gambar berikut:
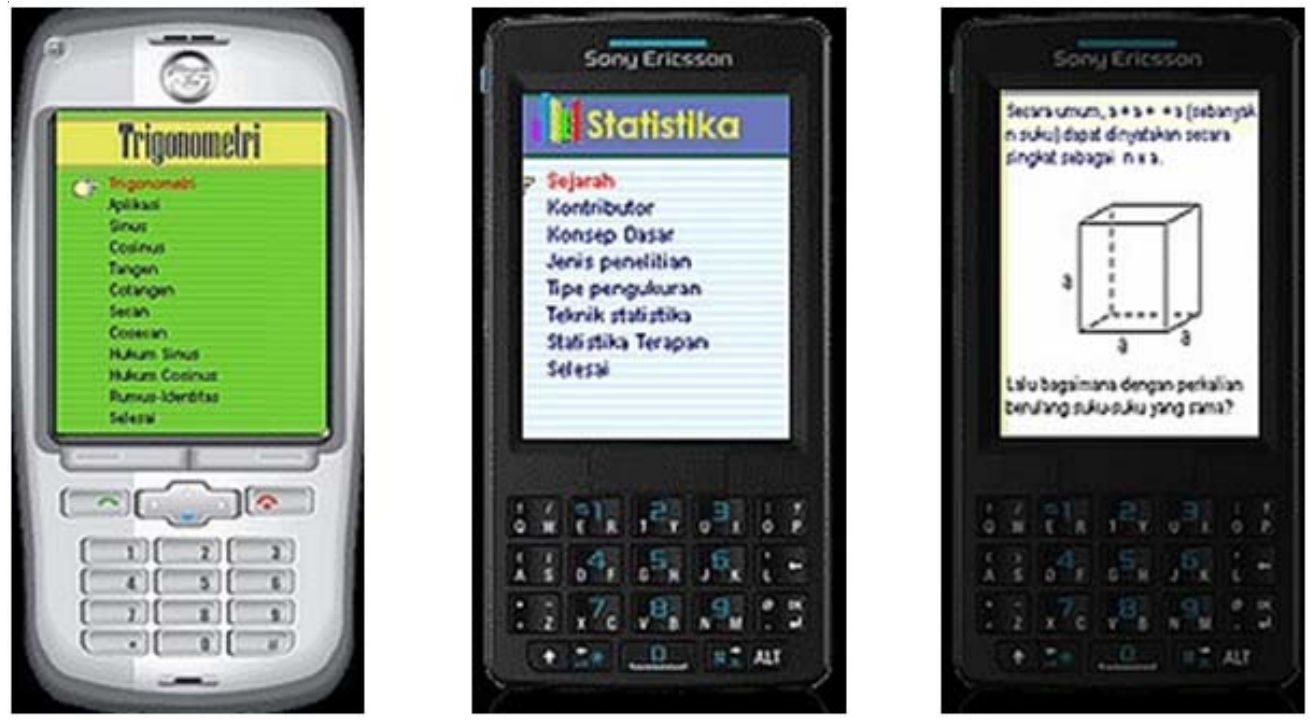

Gambar 3. Mobile Learning untuk Matematika

\section{PENUTUP}

\section{Kesimpulan}

a. Pada masa mendatang akan lahir dan berkembang berbagai bentuk dan model-model pembelajaran yang inovatif sebagai penerapan $m$ learning sesuai dengan kebutuhan, tantangan dan masalah belajar dan pembelajaran yang dihadapi manusia.

b. Kehadiran teknologi seluler menjanjikan adanya peluang yang cukup potensial untuk dikembangkannya model pembelajaran yang inovatif mengingat tingginya tingkat kepemilikan perangkat serta harga perangkat serta tarif yang semakin murah dan fitur yang semakin canggih. 
c. Kelebihan utama dari m-learning adalah proses pembelajaran dapat dilakukan kapanpun dan dimanapun dengan biaya yang relatif murah.

d. Mobile learning merupakan pembelajaran yang dilakukan dengan menggunakan teknologi yang mudah dibawa, pembelajaran antar konteks, tempat, dan pada kondisi peserta didik dalam keadaan mobile.

\section{Saran}

a. Peserta didik agar dapat mengakses mobile learning (m-edukasi) supaya menggunakan HP dengan spesifikasi berikut: 1) size layar adalah $128 \mathrm{x}$ $160,2)$ resolusi yang digunakan 320 atau 340, c) content size-nya maksimal 300 kb, 4) di-support oleh flash lite, 5) memiliki fasilitas polyphonic, 6) memiliki perangkat transfer data, yaitu: bluethot, infra red atau kabel data.

b. Berkembangnya teknologi bergerak, semakin banyak pula peluang untuk mengembangkan dan mengimplementasikan m-learning untuk kegiatan pembelajaran. Perkembangan yang cukup menggembirakan adalah makin meningkatnya kapabilitas pesawat HP, harganya terjangkaunya, oleh karena itu, dalam memilih alternatif teknologi tersebut perlu mempertimbangkan kondisi yang ada supaya teknologi tersebut dapat mendukung pencapaian tujuan pembelajaran.

c. Mobile learning banyak digunakan jenis aplikasi berbasis WAP/WML, aplikasi Java, aplikasi Symbian, dan kemungkinan kedepannya makin banyak muncul aplikasi-aplikasi baru yang inovatif dan menarik, semuanya memiliki ciri khas masing-masing supaya dipilih aplikasi yang sesuai dengan kebutuhan, karakteristik peserta didik, karakteristik konten, dan piranti yang digunakan baik hardware maupun softwarenya.

\section{DAFTAR PUSTAKA}

Balai Pengembangan Multimedia, Mobil Edukasi Sebuah Model Pembelajaran Berbasis Multimedia, Semarang, 2009.

Robso, Robby;" Mobile Learning And Handheld Devices In The Classroom ",Eduworks Corporation, Corvallis, Oregon, USA;IMS Australia, 2003.

Warsita, Bambang, Teknologi Pembelajaran, Landasan dan Aplikasinya, Jakarta: Penerbit Reneka Cipta, 2008.

Websites:http://blog.math.uny.ac.id/ yulialinguistika/2009/10/28/mobile-learning

http://staff.blog.ui.ac.id/harrybs/2009/04/22/ prospek-cerah-pemanfaatan-e-learningsecara-mobile

http://blog.math.uny.ac.id/yulialinguistika/2009/ 10/28/mobile-learning

http://blog.math.uny.ac.id/kholidaagustin/2009/ 10/28/pengertian-mobile-learning

http://one.indoskripsi.com/judul-skripsi-makalahtentang/mobile-learning

http://www.m-edukasi.net

http://www.google.co.id/imgres?imgurl=http:/

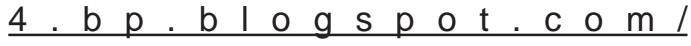
mobile_learning5.jpg\&imgrefurl=http:// teichno.com/mobile learning

http://staff.blog.ui.ac.id/harrybs/2009/04/22/ prospek-cerah-pemanfaatan-e-learningsecara-mobile

http://m.p4tkmatematika.org/2009/11/ trigonometri/

Wijaya, Stevanus Wisnu, Mobile Learning Sebagai Model Pembelajaran Alternatif Bagi Pemulihan Pendidikan di Daerah Bencana Alam Gempa Bumi Yogyakarta, Universitas Sanata Dharma, Yogyakarta, 2006

unuuuuuuuuuuuu 